\title{
14
}

\section{FEDERALISM AND COVID-19 IN ARGENTINA}

\section{Centralisation and hyper-presidentialism}

\author{
Antonio María Hernández and Cristian Altavilla
}

\subsection{Introduction}

Argentina has a federal system comprising 23 states, known as provinces, and the Autonomous City of Buenos Aires, or Ciudad Autónoma de Buenos Aires (CABA), which is the seat of the national capital. ${ }^{1}$ There is substantial asymmetry between the CABA and the provinces ${ }^{2}$ in terms of wealth, territory and population size. Within this federal arrangement, the country has a republican and presidential form of government, with powers separated between the executive, legislative, and judicial branches and direct election of the federal president and provincial governors. The bicameral legislature, called the National Congress, consists of the Senate and Chamber of Deputies. It is elected independently of the executive branch for fixed terms - four years in the case of deputies, and six in the case of senators.

In the elections of October 2019, the Frente de Todos ('Everybody's Front') coalition won 48.1 per cent of the presidential vote, with Alberto Fernández and Cristina Fernández de Kirchner becoming president and vice president, respectively. Frente de Todos is a centre-left coalition of political parties largely Justicialist-Peronist in orientation. It defeated Juntos por el Cambio ('Together for Change'), a centre-right coalition composed mainly of the Republican Proposal and Radical Civic Union parties. The latter coalition had been in power since 2015 under then President Mauricio Macri, who sought re-election.

To turn to the results in the federal legislature, the governing coalition won 43 of the 72 seats in the Senate (59.7 per cent of the total) and Juntos por el Cambio, 29 (40.3 per cent). The outcome in the Chamber of Deputies was far more evenly matched: of the 257 deputies, 119 (46.3 per cent) were of Frente de Todos and 116 (45.1 per cent) were of Juntos por el Cambio. At the provincial level, Frente de Todos governed in 20 provinces at the time of the Covid-19 outbreak, while 
the opposition Juntos por el Cambio was confined to the provinces of Mendoza, Corrientes and Jujuy and, at city level, the CABA.

As for health care in Argentina, the Pan American Health Organization describes the country's health system as 'one of the most fragmented and segmented' in Latin America (PAHO 2017). Likewise, Isuani (2020) asserts that it is characterised, inter alia, by fragmentation, variation in quality, and irrationality. Inequality of access to health benefits and services is compounded by geographical disparities, given the extreme socio-economic differences that are evident from region to region. Such fragmentation is due to the country's federal organisation, which enables each of the 24 jurisdictions to run its own health system, as well as to a historically uneven pattern of development and a lack of national coordination.

Health matters are a concurrent competence among the four orders of government, namely the federal, provincial, municipal, and federal district (i.e. governance pertaining to the CABA). ${ }^{3}$ Health care is provided by a varying combination of employer- and labour-union-sponsored plans, government insurance plans, public hospitals and clinics, and private health insurance. More than 300 health-care cooperatives (200 of which are related to labour unions) provide care for half the population. The Federal Health Council, presided over by the national Minister of Health, is responsible for intergovernmental coordination in health matters and is composed of the highest health authorities of the nation, provinces, and CABA.

It is in this overall context that Argentina's first case of Covid-19 was recorded on 3 March 2020 and its first death on 7 March. Early cases were concentrated in the CABA and its metropolitan area. On 11 March, the government announced a mandatory 14-day-quarantine of returnees to Argentina from highly affected countries such as China, South Korea, Japan, Iran, and the United States. The first domestic restrictions were imposed on 19 March when the federal government ordered a lockdown of the whole country by way of the Decree of Necessity and Urgency (DNU) No. 297.

Adopted at a point when there were still fewer than a dozen cases in the country, the measure had the support of federal legislators, the leaders of all political parties, and the governors of all provinces. It was generally considered the correct step to take in order to buy time in which to strengthen a health system unprepared for the pandemic. Borders were duly closed, all air and land transport was halted, only essential work and movement were allowed, and the population was confined to its homes; on 14 April, a further restriction was introduced that made it obligatory for everyone using public transport or otherwise out in public to wear face masks. Although the initial lockdown was for two weeks, it was extended incrementally until 10 May, at which time certain restrictions were lifted in areas beyond Greater Buenos Aires.

On 23 March, Ministry of Health officials reported that the coronavirus was spreading via community transmission in the CABA and its surroundings, as well as in cities in the provinces of Chaco, Córdoba, and Tierra del Fuego; by 
the end of March, there were 1,054 confirmed cases of Covid-19 and 27 deaths. Then, as later, the major location of infections and fatalities was the province of Buenos Aires, in particular the 40 municipalities that make up the Buenos Aires Metropolitan Area - with a population of more than 12 million people, this is the part of the country where its greatest problems of poverty and social exclusion are found; a related area of concern was the CABA and its 3 million inhabitants, which also forms part of the metropolitan area. Other highinfection locations were the provinces of Santa Fe, Córdoba, Jujuy, Río Negro, Neuquén, and Chaco.

By 3 July, cases of Covid-19 had been found in every province of the country, but it was thought that the pandemic was abating: July concluded with 191,289 confirmed cases, 3,543 deaths, and 83,767 recoveries. However, on 31 July, President Fernández announced that the lockdown restrictions would continue until 16 August, as there had been a record number of cases and deaths in the previous days.

On 9 August, the Ministry of Health confirmed a total of 61,867 new recoveries on that day. This big jump was due to a change in the definition of recovery, which now included (along with discharges from hospitals) mild cases that the Covid-19 monitoring system would discharge automatically 10 days after the onset of symptoms. The recovery rate thus rose to 70 per cent of confirmed cases until that date. President Fernández on 28 August authorised meetings throughout the country of up to 10 people in the open air, providing they used face masks and practised social distancing, and announced that the eased lockdown would be extended again until 20 September. Shortly before then, on 10 August some 10,000 students in San Juan became the first to return to faceto-face classes. Most other provinces either did not attempt this or faced strong resistance from teachers' unions.

The lockdown was extended for three more weeks on 18 September. After reaching a maximum level of infection of 7.591 cases per day in late August, the infection rate started to decrease in Greater Buenos Aires at the beginning of September and was officially said to be 'stabilising'. At the same time, however, the virus increased in spread in the country at large. In the first 15 days of September, the provinces of Córdoba, Jujuy, La Rioja, Mendoza, Neuquén, Río Negro, Salta, Santa Cruz, Santa Fe, Tierra del Fuego, and Tucumán registered exponential increases in case numbers, with most of their health-care systems facing high levels of strain. The lockdown was again extended, now by another two weeks until 25 October.

On 20 October, Argentina, with a population of 45 million, confirmed more than 1 million positive cases, becoming the fifth country in the world and the second in South America to pass this landmark. Three days later, it was announced that the lockdown would continue for another two weeks in provinces with a high daily number of confirmed cases. By 29 October, official figures set the accumulated national total at 30,071 deaths, 1.1 million cases, and nearly 3 million tests (or 64,257 per million inhabitants). 
At the time of writing, the pandemic was ongoing and Argentina's anticipated phase of social and economic recovery had not begun - one consequence of the country's protracted lockdown. Poverty increased from 35.5 per cent at the end of 2019 to 40.9 per cent in the first half of 2020, while inflation had risen over the past 12 months to 35 per cent in November 2020. Similarly, the unemployment rate rose to 13.1 per cent in the second quarter of 2020, compared to 10.6 per cent in the same period in 2019 and 10.4 per cent in 2018, making the increase a 15-year record (Infobae 2020). Economic activity rose by 1.1 per cent in August 2020, but this was still 11.6 per cent lower than in August 2019.

These economic stressors came in addition to the huge fiscal deficit, tax pressures, and enormous external debt with which Argentina was encumbered even before the pandemic broke out.

\subsection{The federal constitutional and legislative framework}

\subsubsection{Division of powers and functions}

Article 1 of the Constitution of 1853 declares Argentina a federal country. The provinces and CABA have their own constitutions and are empowered to create institutions and be governed by them. Although they have to comply with the Constitution, provinces enjoy significant autonomy in the legislative, administrative, and juridical domains. Their governments have three branches (executive, legislative, and judicial). The executive branch is led by a governor, while the legislative branch may be unicameral (as is true of 15 provinces and the CABA) or bicameral (as is the case with eight provinces).

The Constitution divides power and functions between the federal and provincial levels. In this regard, there are three main types of competence: exclusive, shared, and concurrent.

The federal government's exclusive competences pertain to, inter alia, international relations, the armed forces, citizenship, currency, air and aerospace navigation, telecommunications services, and federal intervention, while those of the provinces relate to, for instance, primary education, electoral systems, creating own institutions and establishing local government structures. By contrast, shared competences apply in matters requiring joint decisions, such as the creation of new provinces, the establishment of the capital city, and the enactment of the so-called co-participation regimen - a special tax-sharing arrangement between federal and provincial levels.

As for concurrent competences, they can be decided and implemented independently by any level (Bidart Campos 1998). Both the federal and provincial levels are endowed with powers and functions related to social policies and general welfare: health care, education, science and culture, employment and labour, environmental affairs, and housing are all concurrent competences. The main principle informing the distribution of power is contained in article 121, which states that provinces reserve to themselves all the powers not delegated 
to the federal government. As such, federal powers are limited and enumerated, whereas provincial powers are numerous and indeterminate.

In practice, though, the federal level plays the role of developing and coordinating policies and establishing general guidelines, while the provinces are in charge of implementing and administering these policies. This arrangement is especially apparent in the areas of health care, education, and housing. The federal government plays a key - almost exclusive - role in the areas of social assistance and social security, two competences which have been re-centralised in recent decades.

\subsubsection{Declaration of states of emergency}

In terms of the Constitution, a state of emergency may be declared if there are exceptional social, political, economic, or natural situations that could affect the constitutional order. The power to declare an emergency lies with the National Congress, which can create various emergency powers that are subject to the Constitution. The Congress has to decide whether there is a true state of need, formally declare the emergency, establish its duration, and set out the main measures to be taken. In general, while those measures increase the powers of the state - particularly of the executive - and correlatively limit the rights of individuals, they may not in any way suspend or limit the republican and federal system.

The Emergency powers foreseen by the 1853 constitutional text are federal intervention (article 6) and a state of siege (article 23); those contemplated by amendments to the Constitution in 1994 are decrees of necessity and urgency (DNUs) (article 99(3)) and legislative delegation to the executive (article 76) (Hernández 2012a; Midón 2001).

A state of siege ('estado de sitio' in Spanish), or what is more commonly known as a state of emergency, is provided for in the 1853 Constitution in the event of the emergencies of war ('external attack') and domestic disorder ('internal commotion'). These situations have to meet the requirements, first, of endangering both the Constitution and the authorities created by it, and, secondly, presenting a disturbance of order. Since 1853 there have been 53 states of siege, and in 60 per cent of them the executive acted by decree; exorbitant powers were given to the President; congressional functions saw evident decline; and notable harm was done to individual rights and guarantees (Hernández 2020a, 2012b).

With regard to DNUs, the President is not allowed under any circumstances to issue provisions of a legislative nature, which would be entirely null and void; however, in exceptional circumstances where the ordinary constitutional procedures for the enactment of laws are impossible to follow, he or she may issue decrees on the grounds of necessity and urgency. Even then, the President cannot issue decrees on criminal matters or issues of taxation and electoral or 
political-party systems. As regards formal requirements, the Constitution stipulates that this kind of decree has to be decided together with all the ministers and the Chief of Cabinet and be submitted to the consideration of a joint standing committee of Congress composed of representatives of both houses.

Finally, legislative delegation is a mechanism whereby Congress can delegate the power to regulate certain issues concerning administration and public emergency to the executive arm of government. The legislature empowers the executive to create norms (which, from a purely material point of view, are laws) that determine the content and timing of the decision previously taken and owned, so to speak, by the legislature (Quiroga Lavié 2009: 1172).

\subsection{Preparedness for a national disaster: The institutional framework}

As noted, the national constitution does not specifically provide for institutions to respond to a disaster such as Covid-19. In the case of a health crisis, the Federal Health Council, comprising the federal and provincial ministries of health, could be used, but at the time of this writing it had not convened during the pandemic.

Argentina recorded its first case of Covid-19 on 3 March 2020. At that point, it was in the midst of a severe economic, social, and health crisis that had been formally declared as a public emergency by the National Congress in December 2019. This declaration put in place most of the legal framework within which national and local authorities acted during the 2020 pandemic.

The background to it is that in late December 2019, the National Congress, at the request of the new government, enacted Law No. 27541 which declared a public emergency in nine areas, including economic, financial, fiscal, administrative, pension, tariff, energy, health and social matters, and, under article 76 of the Constitution, expressly authorised the delegation of powers to the President, although in broad terms.

Consequently, when the pandemic reached Argentina in March 2020, a public emergency had already been declared, with the President enjoying legislative delegations and in no need of a further declaration by Congress. The latter commenced its ordinary session on 1 March, but adjourned in the course of the month and did not meet again until mid-May.

\subsection{Rolling out measures to contain the pandemic}

With the coronavirus spreading across the world and its arrival in Argentina imminent, the country's three levels of government began to take measures. Provincial governors were the first to do so, followed rapidly by the federal government; numerous municipalities were also quick to respond to the looming health crisis. Once the federal government had taken the lead, however, the other levels acted within its framework. 


\subsubsection{Taking the initiative}

As stated above, the three levels of governments reacted automatically to the first cases of Covid-19. Indeed, the three levels acted first independently and within their own respective constitutional competencies - although, many local and provincial decisions where considered unconstitutional by local literature. The federal government announced a lockdown throughout the country on 19 March 2020, following which provincial and municipal governments accepted the decision and acted accordingly. Making use of a certain margin of discretion within the federal legal framework, subnational governments added restrictions of their own, with provinces closing borders between each other and many municipalities doing the same with their neighbours.

These actions reflected a lack or failure of coordination in multilevel governance. From the outset, questions emerged about which level of government has constitutional competence to deal with emergencies and which has emergency police powers. The country's literature is unanimous in recognising that health care is a concurrent competence both in times of normality as well as emergency; what was in question was the extent to which each level could limit fundamental rights in exercising its emergency powers.

\subsubsection{Federal action}

In the face of an imminent viral outbreak, President Fernandez on 12 March 2020 issued Decree No. 260, in terms of which the health emergency declared by Congress previously in December was extended for one year 'in accordance with the pandemic declared by the World Health Organisation (WHO) in relation to the coronavirus Covid-19'. The measure was criticised as unconstitutional, on the grounds that no emergency can be established by means of DNUs and that the President is not authorised to extend an emergency already declared by a law of Congress, especially when Congress is still in session - as the Supreme Court of Justice found in San Luis Province v. Estado Nacional [J.A.] (2003-I-188).

One week later, on 19 March, a compulsory lockdown was imposed on the entire country by way of DNU No. 297. This was initially successful, since it had the support of all political parties as well as provincial, CABA, and municipal governments (Porto and Di Gresia 2020; Tortolero Cervantes 2020). There was widespread agreement that mandatory social distancing was the primary way to curb the pandemic, regardless of the constitutional rights it affected.

The first renewals of the lockdown were announced jointly on 26 April by the President, and the governor of the province of Buenos Aires, who belonged to the governing party, and the head of government of the CABA, who was of the opposition party. Later, though, when the President continued issuing decrees in violation of the republican and federal form of state, resistance, accompanied by public protests, grew throughout the country. 
The justification consistently offered for the lockdown was that the health of the population was more important than the economy. Accordingly, the Ministry of Health established an Emergency Operations Centre, or Centro de Operaciones de Emergencia (COE), comprised of epidemiologists and public health experts whose function was to advise the government. Before each renewal of the lockdown, the COE met with the President and national Minister of Health - arguably, the President was seeking thereby to be absolved of responsibility for the social and economic consequences of his actions, as he could claim that, in the name of rationality, he had to follow scientific advice for the good of population health.

From the outset of the pandemic, the federal government implemented a series of socio-economic measures to mitigate the impacts of quarantining. In the first place, it formed an 'economic cabinet' or cabinet committee, albeit without provincial representatives. ${ }^{4}$ This cabinet sought to speed up assistance to small and medium enterprises, vulnerable sectors, and taxpayers financially affected by the lockdown.

As part of these initiatives, the federal government introduced two special financial support packages: the Emergency Family Income package, which provided AMD 10,000 (less than USD 100) to each of more than 8 million people, and the Emergency Assistance Program for Work and Production, aimed at providing economic support to affected businesses and workers for the duration of the pandemic.

It also regulated aspects of business activity that have key socio-economic impacts. Among other things, it froze the price of housing rentals, fixed the maximum prices of basic products, introduced tax exemptions, and prohibited layoffs in the private sector. The President adopted these measures unilaterally by executive decree - although Congress validated most of them, they ought to have come about by means of laws of Congress.

The federal government continued to govern by means of decrees and resolutions as the year wore on. By the end of October 2020, the President had issued 38 DNUs and 12 Delegated Decrees (Cavallini Viale and Ferreyra 2020), facing increasing resistance from the opposition due to Congress's irregular functioning.

Indeed, Congress was bypassed by the DNUs issued by the President, in part because it was closed from the beginning of the lockdown until it began to meet virtually on 13 May. The situation was not helped by the fact that the Senate was presided over by the Vice President, Cristina Kirchner, who steadfastly resisted calls to debate the pandemic response; her son, meanwhile, was the head of the governing-party legislative bloc in the Chamber of Deputies. The opposition was also hindered from taking recourse to judicial measures because both the federal and provincial judiciaries decreed an extraordinary recess for the first months of the pandemic (from March until July), as a result of which - barring a few isolated cases - they all but ceased to operate. 
Moreover, when Congress began to meet virtually on May 13 and thereafter, it gave only brief attention to presidential DNUs - some 20 of these were approved in the Senate meeting of that day. Before the online sessions became operative, both houses had spent considerable time deliberating such a possibility informally and in the media before deciding to proceed with remote sessions paired with the physical presence of a minimum of legislators (restricted to parliamentary office-holders and leaders of legislative blocs). In the Senate, this mixed mode of operation was extended by decree of the Senate leader, yet without the two-thirds votes required to amend the relevant laws pursuant to article 227 of the Senate's Rules of Procedure, ${ }^{5}$ the same occurred in the Chamber of Deputies, where the government extended the remote sessions without the required consensus. ${ }^{6}$

It is evident that the federal government's only strategy in response to the 2020 pandemic was the nationwide lockdown. The national lockdown was the longest in the world and caused a multitude of social and economic, as well as educational and psychological, problems in all sectors of the population, including notably the poor, children and youth, and the elderly. The lockdown was mandatory and sanctions were imposed for non-compliance, all of which resulted in violations of fundamental rights that were not sufficiently reviewed by the judiciary.

The situation was well illustrated by the Single Certificate for Circulation, issuable only by the Ministry of Interior. In terms of Resolution 48/2020 of the Ministry of Interior dated 28 March 2020, permission for any individual to travel outside his or her place of residence depended on the national authority. Thus, all authorisation of movement, and hence of circulation of the population and the resumption of social, economic, and educational activity, rested with the federal government, irrespective of the prevalence - or, in some provinces, or in many areas within different provinces, the virtual non-existence - of the pandemic. By the logic of the Resolution, no one anywhere in the Argentine federation could at any time make a move without the say-so of the centre.

\subsubsection{Provincial action}

All 23 provinces and the CABA formally declared public health emergencies in their respective jurisdictions and according to their own constitutions and laws, thereby enabling their authorities to exercise emergency powers. In many cases, these declarations were effected by executive decrees rather than laws, as required by provincial constitutions. The provinces adopted, and complied with, federal decrees and resolutions, in addition to which they added their own restrictions. In fact, Tierra del Fuego was put under lockdown on 16 March 2020, three days before the rest of the country, while the provinces of Chaco, Misiones, Salta, Jujuy, and Mendoza closed their borders to other countries on 18 March. 
The federation as a system of federal and provincial governments was important in health-care provision. As noted, public health services are under the administration of provinces, the CABA, and municipalities, with more complex institutions falling under provincial governments or the private sector via private health insurance. Provinces thus had to respond to the emergency as well, which many did by repurposing facilities as Covid-19 treatment centres, building new hospitals, or setting up tent and mobile hospitals. Accordingly, provincial COEs were established, with these composed of provincial health ministers and specialists in different fields (e.g. physicians, epidemiologists, and lawyers). COEs decided on measures to combat the pandemic, which in effect subordinated municipal governments to provincial ones, since the former had no say in decisions made by the latter.

Operating within a thin margin of autonomy, provinces were allowed to reduce or expand the activities permitted during the lockdown. In some cases, provinces took measures that went beyond the restrictions of the federal government, such as preventing interprovincial transit and imposing curfews, thus affecting the fundamental rights and federal principles contained in the Constitution. For example, numerous provinces closed the roads leading into them, often by digging up road to make them impassable or leaving trucks parked across them; such actions led to legal challenges.

In general, though, the provinces' role in the quarantine was merely to implement federal decisions, especially regarding DNU 297 and its successive extensions. This is so because any measures implemented by a province were carried out within the national legal framework. The DNU 297 measures were highly restrictive and imposed a rigid framework within which local authorities were also required to act.

Like their federal counterpart, the provinces were prone to a state-level version of hyper-presidentialism. Provincial legislatures and municipal councils were not fully operational, though there were exceptions. Some provincial legislatures held meetings that were attended in person, in which they adhered to hygiene and safety protocols (as is the case in Neuquén, San Juan, Catamarca, Tucumán, and Jujuy, among others) while in other provinces, legislatures proceeded with remote sessions (as in Córdoba, Santa Cruz, Misiones, or La Rioja, for example) or a mixture of online participation and a minimum physical presence of legislators (as in San Luis and Formosa). Although provincial legislatures were operational in one way or another, the general trend was for government by gubernatorial decree, or even by resolutions or administrative decisions issued by lower-level officials such as provincial COEs, which are not legislative bodies (Hernández 2020a).

The role of provincial government was far from insignificant. Provinces are in charge of police forces, which were drawn on extensively to enforce pandemic control measures. Crucially, too, provinces are responsible for the administration of the health-care system and all it entails, ranging from hospitals and health centres to personnel, resources, and infrastructure. 


\subsubsection{Local government action}

Municipal governments also had an important role to play in the 2020 pandemic, primarily because their broad competences in health matters are concurrent with those of the provincial and federal levels. Of the 25,751 facilities that make up Argentina's health system, a total of 4,056 (15.75 per cent) depend directly on municipal governments, which all developed prevention, containment, and support activities in the fight against Covid-19. Their role - specifically the role played by primary health-care centres - was especially critical given their close, direct relationship with the most vulnerable sectors of the population, which are present in small towns as well as intermediate cities and large metropolitan areas.

This immediacy led some local governments to take preventive measures ahead of the federal or respective provincial government. For example, Bahía Blanca in the province of Buenos Aires issued Decree 317/2020 on 12 March 2020 prohibiting large-scale public events and activities; a few days later, other municipalities followed suit, among them La Plata, Tandil, Olavarría, Pilar, Avellaneda, Mar del Plata, and Brandsen (Malavolta and Pulvirenti 2020).

Some local government orders were controversial, such as blockades of interprovincial or municipal boundaries or the imposition of curfews. A notable case was the local government of Puerto Iguazú, which announced the closure of the Tancredo Neves Bridge linking Brazil and Argentina but which was prevented by a warning from the Federal Judge of El Dorado (Azarkevich 2020).

\subsubsection{Intergovernmental relations}

Cooperative and coordinated federalism are fundamental to the constitutional reform of 1994 (Hernández 2009), but the intergovernmental relations (IGR) they entail were not given full effect to during the pandemic or, for that matter, before it. The federal government's hyper-presidentialism and attendant centralised approach meant that Congress, provinces, the CABA and local governments were marginalised (Hernández 2020a, 2020c) - arguably, a serious error to make in the management of Covid-19 in what is, after all, the eighth-largest country in the world.

This occurred notwithstanding that certain DNUs refer explicitly to multilevel coordination in implementing control measures. Article 3 of DNU No. $355 / 2020$ stipulates that federal authorities, 'in coordination with their peers from the provincial jurisdictions, from the CABA and from the municipal authorities, each one in the scope of their competences, will arrange the measures .... However, article 2 of the same decree in effect subordinates subnational governments and curbs their leeway for movement, since only the Chief of Cabinet of the federal government is authorised to make exceptions to the orderly exit from lockdown, exceptions which have to be requested by provincial governments. Similarly, DNU No. 408/2020 permits provinces to determine 
their respective activities and protocols, only to constrict them tightly again by reaffirming that it is the Federal Ministry of Health and Chief of Cabinet that have the final say on these matters.

At an institutional level, a variety of spaces exist for deliberating on and implementing joint, consensual intergovernmental decisions, in particular federal councils such as the previously mentioned Federal Health Council, along with the Federal Education Council and Investment Education Council. However, the latter were inactive and unutilised in the 2020 pandemic response, an act of omission that amounted to a missed opportunity for fostering IGR generally and so, among other things, averting or mitigating the conflicts that would inevitably arise in a nationwide effort of this kind. For instance, the decision of the federal government to centralise the purchase of respirators prevented the provinces of Mendoza, Jujuy, Chubut, and Corrientes from buying their own even though they had already placed orders with the company concerned (Mozetic 2020) and as a consequence of that decision, these provinces were unable to buy those respirators.

To turn from vertical to horizontal IGR, inter-state cooperation was rare. In Patagonia, for instance, an enormous region encompassing the provinces of La Pampa, Neuquén, Río Negro, Chubut, Santa Cruz, and Tierra del Fuego, all but two interprovincial initiatives were carried out: the creation of the Interprovincial Commission for Monitoring the Epidemiological Situation (Covid-19), set up by the governors of Neuquén and Río Negro on 19 April 2020; and a meeting of the Patagonian Forum of the Superior Courts of Justice to prevent and minimise the pandemic's effects on the administration of justice.

Far more common was inter-state conflict. A case in point was that between the neighbouring provinces of Corrientes and Chaco. Separated by a river and joined by a bridge, the one province, Chaco, had a high level of Covid-19 infection, while the other, Corrientes, had none; their dispute turned around two contradictory court rulings to do with medical personnel living in the province of Corrientes but working in Resistencia, the capital of Chaco.

When the government of Corrientes prohibited them from crossing the bridge between the two provinces, the federal judge of Resistencia ordered the opposite; in turn, the province of Corrientes resorted to the federal judge of Corrientes (the city of the same name), who ruled that this resolution was unenforceable in the province of Corrientes's jurisdiction. Once again, the federal judge of Resistencia ordered Corrientes not to prevent the medical personnel from performing their duties in accordance with the federal government's emergency decree. This precautionary measure was ratified by the federal judicial chamber of Resistencia in a resolution, dated 20 April 2020, that allowed medical personnel from Corrientes entry to Chaco (Pulvirenti 2020).

A similar issue arose between the federal court of Rio Cuarto (province of Córdoba) and the province of San Luis. In response to a precautionary measure issued by the former, which ordered the lifting of the blockade imposed by the province of San Luis on national and provincial routes connecting both 
jurisdictions, the federal judge of San Luis issued a counter-measure requested by the provincial government itself. In the meantime, an amparo action was filed before the federal judge of Río Cuarto by four entities - representing thousands of citizens of the south of the province of Córdoba - in regard to the fundamental rights violated by the blockade ordered by the provincial government of San Luis.

In view of the conflict of jurisdiction, the federal judge of Río Cuarto referred the case to the Supreme Court of Justice of the Nation, which has competence in such matters under article 117 of the Constitution. Its ruling was awaited at the time of writing, and it was anticipated that it would clarify the position not only as regards Córdoba and San Luis but also the several other provinces and municipalities which had declared similar prohibitions of interprovincial or inter-municipal transit. The Supreme Court had requested that the provinces of San Luis, Córdoba, Corrientes, Salta, and Formosa submit reports detailing citizens' complaints about the prohibitions. In one such instance, it ordered the province of Corrientes to allow a person to enter the provincial jurisdiction so as to assist his mother, who was ill with cancer (Maggi, Mariano v. Provincia de Corrientes, 10 September 2020).

\subsubsection{Intergovernmental fiscal relations}

The pandemic had a highly adverse impact on the economy, all the more so given that Argentina was already in the midst of a major economic crisis when Covid-19 broke out. Unemployment rose to 13.1 per cent in the second quarter of 2020, while between March and November, poverty rates increased and inflation climbed to 35 per cent. Due to the slump in economic activity, tax collection decreased, thus hampering federal transfers to provinces. Fiscal federalism is highly centralised in Argentina, where it is the federal government that collects the lion's share - nearly 82 per cent - of tax revenue generated by the country. Federal taxes represent 32 per cent of the tax burden as a percentage of gross domestic product (GDP), while provincial taxes represent only 5.6 per cent (Altavilla 2019).

Under normal circumstances, the federal government provides provinces with resources by way of various transfers. Chief among these is the co-participation regime, or Régimen de Coparticipación Federal de Impuestos (RCFI), which accounts for a little more than 50 per cent of all federal transfers. Provincial finances are heavily dependent on these transfers. Most provinces rely on them for more than 50 per cent of their revenue, and in some extreme cases, for nearly all of it: in Formosa, federal transfers cover as much as 94.5 per cent of its budget, in La Rioja, 92.5 per cent, in Catamarca, 90.2 per cent, in Santiago del Estero, 89 per cent, and in Chaco, 88.1 per cent (Altavilla 2019).

As mentioned, from the outset, the federal government adopted measures to mitigate the lockdown's socio-economic impacts. Between March and October 2020, it transferred AMD 1.55 trillion to the provinces by means of discretionary 
federal funds, such as food programme funds or the fund, Contributions from the National Treasury, or Aportes del Tesoro National (ATN). As these are discretionary funds, the federal government was free to distribute them to any province according to its own criteria.

Furthermore, in April 2020, it created the Provincial Financial Emergency Programme, or Programa para la Emergencia Financiera Provincial (PEFP), capitalised to a total amount of AMD 170 billion (made up of AMD 60 billion from the ATN fund and ADM 110 billion from the Provincial Development Trust Fund (FFDP)). Predetermined federal transfers continued to be assigned to provinces. However, since transfers are composed of federal taxes, their amount depends on tax collection; during the pandemic, tax collection declined, as did the amounts directed to provinces. As such, transfers via the FFDP compensated for the decrease in RCFI amounts.

Critical problems in intergovernmental fiscal relations surfaced, nonetheless. For one, at the time of writing, the federal government had not yet distributed all the FFDP's budgeted amounts (to date, only AMD 46 billion of AMD 60 billion had been transferred from the ATN fund). For another, some reports show that the distribution of resources to provinces has been linked less to their degree of Covid-19 infection than to whether they are governed by the national ruling party (Aerarium 2020). Looking at federal transfers as a whole, only five provinces received more resources in 2020 than in the previous year (Buenos Aires, La Rioja, Neuquén, Santa Cruz, and the CABA); the other 19 provinces received less than before.

Certain decisions by the President caused major intergovernmental conflict. In a sudden, unilateral decision, he issued decree No. 735 on 9 September on tax relations which provided for a 1.18 per cent reduction of the co-participation regime of the CABA (in opposition hands) to be granted to Buenos Aires province, ostensibly to help tackle the pandemic, and immediately sent a bill to Congress to reduce the tax share due to the CABA. The bill, approved by the Senate, was in relation to the 2016 Security Transfer Agreement. In that year, federal and city governments agreed to transfer more than 20,000 federal police to the CABA since the latter were providing services in the city but were funded by the national budget. For this reason, the CABA's tax share was set at 3.50 per cent. Decree 735 reduced this to 2.32 per cent, while the bill passed in the Senate reduced the percentage further to 1.4 per cent. The CABA rejected the federal government's policy as unconstitutional and approached the Supreme Court, whose decision was pending at the time of this writing.

Other serious infringements of federalism also occurred, such as the fact that the process of transferring companies providing water and electric power services under the federal jurisdiction to the province of Buenos Aires and to the CABA were stopped. Also, in the proposed federal budget most of the transport subsidies are targeted at the Buenos Aires Metropolitan Area at the expense of other jurisdictions, which has led to claims by the mayors of the metropolitan areas of Córdoba, Rosario, Salta, and Bariloche, among others. ${ }^{7}$ 
In short, the main economic measures were taken at the centre, while the intergovernmental fiscal structure was not adapted in response to the pandemic. The pandemic and lockdown worsened the country's economic situation, both generally and specifically in the provinces. Federal transfers depend on tax collection, and because tax collection declined, federal amounts paid to the provinces were reduced - at the same time, there were no compensatory measures to mitigate the provincial financial crisis.

\subsection{Findings and policy implications}

Emergency powers should conform to the principles and rules of Argentina's constitutional, democratic, liberal, and republican order. The standards set by the jurisprudence of the Supreme Court of Justice and of the Inter-American Court of Human Rights should be applied, based on reasonable and proportional limitations to fundamental rights. In contrast, what occurred in practice is that most of the decisions made and measures taken in response to the pandemic were adopted through presidential decrees with a centralist bias and in violation of the concurrent powers of subnational entities and the formal division of power. There was a de facto subordination of provinces, the CABA and local governments to the federal government, rather than coordinated federalism based on adequate IGR.

Although the country's executive authorities are endowed with the highest of powers for dealing with exceptional situations, this does not mean that Congress and other legislative bodies should cease to play their oversight role with regard to emergency measures - the same is true as well at the subnational level. In responding to emergencies, the country's measures need to balance effectiveness, on the one hand, with democratic legitimacy and constitutionality, on the other. This is not easy to do, but if the mistakes of the past are to be avoided, it is a challenge that has to be taken up (Hernández 2020d).

Argentina has returned to hyper-presidentialism in which power is concentrated in the hands of the President beyond what is prescribed in the Constitution, a situation that stands to the detriment of the division of powers in multilevel government and the principles of constitutional democracy (Hernández 2012b; Hernández et al. 2016; Nino 1992a, 1992b). The country has often suffered from circumstances such as these, which point to low institutional capacity, a weak culture of legality, and a strong culture of corporatism and centralism (O'Donnell 1992). The executive branch also reverted to its old habit of using emergency powers for personal or political advantage.

In view of the complexity of the pandemic, deliberation by legislative bodies should not have been dispensed with. The national union (mentioned in the preamble of the Constitution as one of the objectives of the nation) that needs to be defended in times of threat should be imagined as a plural, open society and sustained by democratic consensus rather than centralist thinking. The pandemic 
and the consequences of its governance have now been added to Argentina's many other national problems.

In conclusion, the pandemic has brought out new issues and has revitalised some old problems that have affected the Argentine Federation for a long time. Centralised decision-making without consulting the provinces and municipalities has damaged the already weakened intergovernmental relation network. While at the beginning of the pandemic, the process of decision-making seemed to follow some intergovernmental logic (previous reunion between the president and governors), however, soon thereafter the practice of decision-making turned to be centralist (Hernández 2020b). No institutional channel was used (such as the existing federal councils) not even a new one was established (for instance, some federal emergency committee).

Undoubtedly, federal institutions were helpful and useful in addressing the pandemic because of the effectiveness of the preventive measures that were implemented, and the swiftness with which they were implemented. However, a great opportunity to improve intergovernmental relations was lost, and Argentine federalism failed, in some way, to address this emergency situation from a federal perspective, using all the institutional resources provided by the Constitution. Yet, the pandemic is still ongoing - and while it is not yet feasible to reach a definitive conclusion - it can be said that a window of opportunities for improving intergovernmental relations is still open.

\section{Notes}

1 Greater Buenos Aires, also known as the Buenos Aires Metropolitan Area, is an agglomeration consisting of the CABA and 40 adjacent districts within the province of Buenos Aires.

2 The 23 provinces are Buenos Aires, Catamarca, Chaco, Chubut, Córdoba, Corrientes, Entre Ríos, Formosa, Jujuy, La Pampa, La Rioja, Mendoza, Misiones, Neuquén, Río Negro, Salta, San Juan, San Luis, Santa Cruz, Santa Fe, Santiago del Estero, Tierra del Fuego, and Tucumán.

3 See Hernández $(2003,2009)$; on concurrent municipal powers, see Marchiaro (2020a, 2020b).

4 This cabinet was composed of, among others, the Chief of Cabinet; the federal Economy Minister, Minister of Productive Development, and Minister of Labor, Employment and Social Security; the president of the Central Bank; the president of the AFIP (Federal Administration of Public Revenues); and the Secretary of the Treasury. All of these office-holders were federal public servants.

5 For this reason, an amparo action (special proceedings for urgent protection of constitutional rights) was filed before the Supreme Court on 22 September by the Interbloque de Juntos por el Cambio of the National Senate, which brings together the opposition parties Republican Proposal and Radical Civic Union parties, with Antonio María Hernández and Ricardo Gil Lavedra as lawyers for the plaintiff.

6 An amparo action was also filed on 8 September by the Interbloque de Juntos por el Cambio of the Chamber of Deputies, with Antonio María Hernández and Juan Vicente Sola as lawyers for the plaintiff.

7 Practically 90 per cent of the subsidies are provided to the Buenos Aires Metropolitan Area, with the balance going to the main cities of the country. 


\section{References}

Aerarium. 2020. Transferencias federales a provincias. Automáticas y discrecionales: ¿quiénes ganan $y$ quiénes pierden?, https://434938b4-9b8e-4a95-9c6f-bd5ed403809f.filesusr.com/ ugd/2f2254_5db2cd19bae04127b7819a2a3c2547cc.pdf (accessed on 11 December 2020).

Altavilla, Cristiàn. 2019. Decentralization, Intergovernmental Relations and Regional Inequality in Argentina. Conference at Harvard Law School, 18 April.

Azarkevich, Ernesto. 2020. 'Coronavirus in Argentina: Finally Puerto Iguazú Did Not Close Its Border with Brazil', Clarín, 25 March.

Bidart Campos, Germán. 1998. Manual de la Constitución Reformada. Vol. I. Buenos Aires: Ediar.

CavalliniViale, Delfina and Leandro Ferreyra. 2020. 'Cincuenta Decretos de Fernández', Palabras del Derecho, 19 May.

Hernández, Antonio María. 2003. Derecho Municipal. Mexico: UNAM.

Hernández, Antonio María. 2009. Federalismo y Constitucionalismo Provincial. Buenos Aires: Abeledo Perrot.

Hernández, Antonio María. 2012a. ‘El Poder Ejecutivo', in Hernández, Antonio María (ed.) Derecho Constitucional. Buenos Aires: La Ley.

Hernández, Antonio María. 2012b. Fortalezas y debilidades constitucionales. Una lectura crítica en el Bicentenario. Buenos Aires: Abeledo Perrotáá.

Hernández, Antonio María. 2020a. Emergencias, Orden Constitucional y COVID-19 en Argentina. Buenos Aires: Rubinzal Culzoni Editores.

Hernández, Antonio María. 2020b. 'El Retorno Al Peor Pasado Centralista', La Nación, February 27.

Hernández, Antonio María. 2020c. 'Federalismo y Covid-19', Clarín, 24 April.

Hernández, Antonio María. 2020d. 'Las Emergencias y el Orden Constitucional', Clarin, 23 March.

Hernández, Antonio María, Daniel Zovatto and Eduardo Fidanza. 2016. Segunda Encuesta de Cultura Constitucional. Argentina, una Sociedad Anómica. Buenos Aires: Eudeba.

Infobae. 23 September 2020. 'Tasa de Desempleo de Argentina Trepa a 13,1\% en Segundo Trimestre: Oficial', https://www.infobae.com/america/agencias/2020/09/23/tasa-dedesempleo-de-argentina-trepa-a-131-en-segundo-trimestre-oficial-3/ (accessed on 29 November 2020).

Isuani, Aldo. 2020. 'Frente a la Pandemia: ¿tenemos un Sistema de Salud?', Clarín, 1 October.

Malavolta,Víctor and Orlando Pulvirenti. 2020. 'El Federalismo y el Municipalismo en Tiempos de Pandemia', 28 April, http://www.saij.gob.ar/victor-malavolta-federalismo-municipalismotiempos-pandemia-dacf200078-2020-04-28/123456789-0abc-defg8700-02fcanirtcod? \& (accessed on 11 December 2020).

Marchiaro, Enrique. 2020a. 'Cierres Municipales y Pandemia', DPI, Diario Administrativo, 273, 7 April.

Marchiaro, Enrique. 2020b. 'Son Válidos Los Cierres Municipales de Circulación y Actividad General en Tanto No Impidan Los Servicios Esenciales', in Cristiàn Altavilla and Candela Villegas (eds), Los Desafíos del Derecho Frente a la Pandemia COVID-19. Mirada del Derecho Argentino con Aportes del Derecho Comparado, pp. 133-36. Buenos Aires: Universidad Siglo 21 - IJ Editores.

Midón, Mario. 2001. Decretos de Necesidad y Urgencia. Buenos Aires: La Ley.

Mozetic, Daniela. 2020. 'Cruce Entre Ginés y Gobernadores por la Compra de Respiradores', Perfil, 28 March.

Nino, Carlos Santiago. 1992a. Fundamentos de Derecho Constitucional. Buenos Aires: Astrea. 
Nino, Carlos Santiago. 1992b. Un país al margen de la ley. Buenos Aires: Emecé.

O’Donnell, Guillermo. 1992. 'Delegative Democracy'. Kellogg Institute working paper no. 172.

Pan American Health Organization (PAHO). 2017. 'Health in the Americas: Argentina', https://www.paho.org/salud-en-las-americas-2017/?p=2706 (accessed on 11 December 2020).

Porto, Alberto and Luciano Di Gresia. 2020. El Rol de los Gobiernos Subnacionales (Provinciales y Municipales) en la Pandemia Covid-19, 13 April. Universidad Nacional de La Plata.

Pulvirenti, Orlando. 2020. Tres Fallos y el Federalismo en la Pandemia, Microjuris.com, MJ/ DOC/15283/AR, 14 April.

Quiroga Lavié, Humberto. 2009. Derecho Constitucional Argentino. Vol. II. Santa Fe: Rubinzal-Culzoni.

Tortolero Cervantes, Francisco. 2020. 'La Pandemia como Oportunidad para Relanzar el Rol de las Entidades Subnacionales Latinoamericanas', in Nuria González Martín and Diego Valadés (eds), Emergencia Sanitaria por COVID-19-Federalismo. México: Instituto de Investigaciones Jurídicas de la UNAM. 


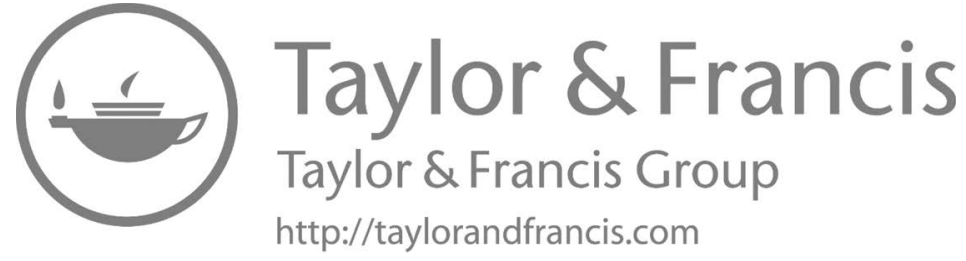

